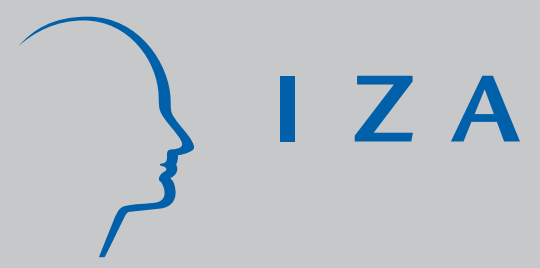

IZA DP No. 1166

Other Forms of Employment: Temporary Employment Agencies and Self-Employment

PernillaAndersson

Eskil Wadensjö

J une 2004 


\title{
Other Forms of Employment: Temporary Employment Agencies and Self-Employment
}

\author{
Pernilla Andersson \\ Swedish Institute for Social Research, \\ Stockholm University \\ Eskil Wadensjö \\ Swedish Institute for Social Research, \\ Stockholm University and IZA Bonn
}

\section{Discussion Paper No. 1166 June 2004}

IZA

\author{
P.O. Box 7240 \\ 53072 Bonn \\ Germany
}

Phone: +49-228-3894-0

Fax: +49-228-3894-180

Email: iza@iza.org

\begin{abstract}
Any opinions expressed here are those of the author(s) and not those of the institute. Research disseminated by IZA may include views on policy, but the institute itself takes no institutional policy positions.
\end{abstract}

The Institute for the Study of Labor (IZA) in Bonn is a local and virtual international research center and a place of communication between science, politics and business. IZA is an independent nonprofit company supported by Deutsche Post World Net. The center is associated with the University of Bonn and offers a stimulating research environment through its research networks, research support, and visitors and doctoral programs. IZA engages in (i) original and internationally competitive research in all fields of labor economics, (ii) development of policy concepts, and (iii) dissemination of research results and concepts to the interested public.

IZA Discussion Papers often represent preliminary work and are circulated to encourage discussion. Citation of such a paper should account for its provisional character. A revised version may be available on the IZA website (www.iza.org) or directly from the author. 


\section{ABSTRACT \\ Other Forms of Employment: Temporary Employment Agencies and Self-Employment ${ }^{*}$}

In most industrialized countries the majority of employed people are full-time employees with a non-temporary job and work at a workplace of the company in which they are employed. They are making careers at the employer they are employed by and most work-place changes are to other jobs of the same type. But it does not include large groups in the labour market. Many of those who have tenured positions work part-time, not full-time, and many both full-time and part-time workers have fixed-period contracts, contracts which only guarantee employment for a specified period of time. Some demographic groups are overrepresented among those with those types of jobs, young people, women, immigrants, ethnic minorities, and older workers, who to a large extent for different reasons do not have a very strong position in the labour market. In this paper two groups outside the core of full-time employees are analyzed: those employed in temporary employment agencies, and the selfemployed. The size and composition of both groups have changed during the last decade. The number employed by temporary employment agencies has increased in Western Europe as a consequence of deregulation of this sector in the 1990s, and the composition of the selfemployed has changed from mainly being farmers to being business-owners in various sectors. We will use Sweden as an example, but the Swedish experience is not unique. Other countries have similar and in many cases more of those types of employment.

JEL Classification: J15, J23, J40, J61

Keywords: contingent labour, temporary work, temporary agency work, self-employment, immigrant workers

Corresponding author:

Eskil Wadensjö

Swedish Institute for Social Research

Stockholm University

SE 10691 Stockholm

Sweden

Email: Eskil.Wadensjo@sofi.su.se

\footnotetext{
${ }^{*}$ We would like to thank seminar participants at the SO conference in Stockholm May 2003 and at the European Science Days (ESD) in Steyr in July 2003 for helpful comments on earlier versions. We will especially thank Henry Ohlsson and Donald Storrie. Financial support from IFAU is gratefully acknowledged.
} 


\section{Many forms of employment}

During most of the $20^{\text {th }}$ century the employee share of all employed increased. A society of mainly farmers and their employees turned into an industrial society. Most of the jobs in manufacturing and even in other sectors such as the expanding public sector tended to be long-term. Seasonal variations and seasonal employment and unemployment diminished gradually and the post-war business cycle variations were small in Sweden up to the 1990s. Job security increased gradually and encompassed not only the public sector and white-collar workers in the private sector but also blue-collar workers in the private sector. Long-term full-time jobs became the dominant form in the Swedish labour market. This development was codified by the Law on Employment Security from 1974.

At about the same time as the full-time long term job was codified as the norm, other types of employment became more frequent. In the 1970s female employment increased strongly and a large part of the women who entered the labour market worked part-time. It also became more common among young people to combine studies and part-time work, and a special part-time pension system was introduced in 1976 leading to a surge of part-time work among those aged 60-65. Also, the founding of new, small private businesses expanded outside the agricultural sector. Self-employment in various forms became more frequent. Later in the 1990s temporary employment agencies became a new and rapidly expanding form of non-conventional employment.

We have new forms of employment, and old forms of employment have partially changed character. In this study we have chosen to concentrate on two forms of new or changed forms of employment: employment in a temporary employment agency and employment as self-employed. One of our aims is to see if those who work in the two forms are alike in some respects.

\section{Temporary employment agencies}

Temporary employment agencies have existed in Sweden for many years, even if they only became legal in the beginning in the 1990s. Up to that time (from 1935 to 1992) they were seen as private labour exchanges and as such not allowed. From a low level of activity in the early 1990s, which was a recession period in Sweden, they expanded so 
that they now employ $0.5-1.0$ per cent of the labour force. ${ }^{1}$ The market share is higher in some other European countries that have a longer history of temporary employment agencies, so a further expansion could be expected. ${ }^{2}$ From starting out by mainly hiring out office personnel in the Stockholm area, which started already before it became legal, their activities have broadened to other occupations and other parts of Sweden, even if Stockholm still has a very large market share. Compared to other countries it is an industry with high union activity and with national agreements regulating the working conditions and minimum working hours. The national agreements are not binding on the local level however so the local union may agree to changes in the agreements.

Why are some people hired from temporary employment agencies instead of being employed directly on a regular basis? The answer to this question has to be found on the demand side, the supply side or a combination of the two sides of the labour market. There are some different answers to this question put forward in the literature in the field. ${ }^{3}$

The first explanation for the phenomenon is that the temporary employment agencies combine many part-time and part-year jobs to full-time and full-year jobs. In many cases employers only have a demand for people to work with certain tasks for a few hours a day, or full-time for only a few days or weeks. Most people want to work more than that. In principle a person could combine a number of part-time or part-year jobs to full-time employment himself, but it takes time and it could lead to a disadvantage regarding different forms of fringe benefits such as insurances which may be dependent on a minimum working time with one employer. The temporary employment agency combines several part-time or part-year jobs to full-time jobs (or longer part-time jobs).

A second explanation is based on that it is costly to recruit people. There are costs for advertisements, interviews, training etc. These costs may be of minor importance when the employment is expected to last for a long period, but they could be prohibitive if the expected period is short. And there is a demand for short employment spells, for example

\footnotetext{
${ }^{1}$ See Affärsvärlden (2003) and Bemanningsföretagen (2004).

${ }^{2}$ See Storrie (2002) for a survey and analysis of the size of temporary employment industry in various countries. See also Friberg et al. (1999) and Fridén et al. (2000).

${ }^{3}$ For an analysis see Houseman (1997).
} 
to match short-run variations in product demand, at seasonal variations, when regular employees are on sick leave, and for the time when recruitment for a permanent position is carried out. When an employer uses a temporary employment agency, the agency covers most of the recruitment costs but the agency can distribute these costs over many hiring companies. Another related advantage for the company hiring workers is that the recruitment often is faster if a temporary employment agency is used instead of alternative methods.

A third explanation is that the temporary employment agencies are better at finding people with the required competence, maybe especially in comparison to small firms. In such cases a job in a temporary employment agency may also serve as a trial employment.

The second and third explanations build on two types of uncertainty. The second explanation relates to uncertainty regarding the extent and duration of the demand for labour, and the third on uncertainty regarding the quality of the supply of labour. ${ }^{4}$

The fourth explanation builds on that laws and collective agreements make it costly for employers to reduce the workforce or change its composition. It is much easier to change the volume or composition of the personnel hired from a temporary employment agency. If a firm does not want to hire a worker any longer the temporary employment agency may find another firm willing to hire the same worker. Increased employment security according to law or agreement may lead to an increased demand for the services of temporary employment agencies. ${ }^{5}$

In the United States a fifth explanation has also been an important part of the debate and the research on the temporary employment agencies. That is, by hiring a temp instead of employing the worker himself, an employer is able to reduce the wage costs due to that the wages and especially the insurance costs (e.g. for health insurance) are lower for those hired from a temporary employment agency than for those hired directly by the employer. ${ }^{6}$ Sweden has a different industrial relation system with collective agreements

\footnotetext{
${ }^{4}$ See Milner and Pinker (2001) for a theoretical analysis of the two models of explanation.

${ }^{5}$ See Autor (2003) and Miles (2000) for studies of the importance of the stricter rules for employment protection on the development of temporary employment agencies in the United States.

${ }^{6}$ See Golden (1996) for a study which gives some support to this hypothesis.
} 
covering most of the labour market including those who work in temporary employment agencies. This means that the lower wage cost explanation is probably of less relevance regarding the Swedish labour market.

There is a debate on how the different explanatory factors could be used to explain the expansion in the temporary employment industry. This is especially so for the legal framework. In the United States, employment protection has gradually been enhanced mainly by decisions made in the courts on the state level. These changes have taken place at different times in different states and that facilitates studies of the effects of the changes. The studies show that the changes have the expected effects - an increase in the demand for the services of the temporary employment agencies. Another result is that a high union density means a higher market share for the temporary employment agencies. This fact, however, cannot contribute to explain the development over time since union density has declined during the last decades in the United States.

The first of the five explanations presented above is that the matching in the labour market is facilitated by the temporary employment agencies (a combined demand and supply side explanation). The other four explanations are different forms of demand side explanations - the employers get lower costs by utilizing temporary employment agencies. There may also be supply side factors. Some people may prefer a job in a temporary employment agency compared to an ordinary job due to that it is more flexible as regards the number of working hours and also due to that it makes it easier to switch between different places of work.

\section{Self-employment}

As mentioned earlier, self-employment outside the agricultural sector has tended to increase in many European countries. Self-employment has many different forms. It can be full-time employment or part-time employment without other forms of labour income, with or without employees. In some cases the self-employed only sells his services to one company, which means that it is more like employment but without the job security guaranteed by law. It can also be an activity complemented by other types of labour income. A typical example is an MD employed by the county council who also has a private medical practice. The composition of the two types of labour income (earnings 
and income from self-employment) varies considerably. In some cases the income from self-employment dominates and earnings are only marginal. In other cases the selfemployment is only a way of getting some extra income alongside a full-time employment. Between those two cases there are all forms of mixes of self-employment and being employed.

There are many different reasons for becoming self-employed. For some people it is the preferred form of employment because it gives independence from employers and in some cases leads to high or very high incomes (or at least the hope of high incomes). For another group of people it is just a means of obtaining extra income outside of the regular job. For a third group of people it is a way of getting employment due to difficulties in being hired when searching for a job. The differences in motives mean that we should not expect the group to be homogenous.

\section{Data}

The data utilized for this study of self-employed and employed in temporary employment agencies are for the year 1999. The common basis for the data is the Register Based Labour Market Statistics (RAMS) at Statistics Sweden. This register is based on data collected for administrative purposes. Included in the register are all who are resident in Sweden at the end of each year. It is a combination of the Register for the total population (RTB), the Tax Register (KU), the Register for income and wealth (IoF), the register of employers (FDB), the register of education (U-REG), register of people in education (RPU) and the register for pensions and other transfer payments. ${ }^{7}$ This study is using the RAMS register for people aged 16 to 64 in December 1999. In most cases only those who were employed in November 1999 are included. ${ }^{8}$ The population with all employed aged 16-64 consists of about 3.9 million individuals.

\footnotetext{
${ }^{7}$ See SCB (1999).

${ }^{8}$ All who have had some paid work in one specific week in November are counted as employed.
} 


\section{Employed by temporary employment agencies}

We have a unique data set that covers everyone aged 16-64 who is employed by temporary employment agencies (TEA) in Sweden in November 1999, with information on their employment status in 1998 and 2000. We have information on their age, gender, marital status, immigrant status, education, region, income etc.

The classification of firms as TEA started with a register from Statistics Sweden with names and addresses of firms in an industry which contained many of the firms in the temporary employment agency industry even if most of them were other types of firms. Additional temporary employment agencies were found in newspaper ads, in telephone catalogues (the "yellow pages") and the list of members of the organisation of temporary employment agencies (SPUR). Telephone calls in the spring of year 2000 were used to determine if a firm on the list was a TEA or not in $1999 .{ }^{9}$

Individuals in this population were identified as those who worked in a TEA in 1999 by letting Statistics Sweden match firms with individuals who were employed in one of these firms in November. The population contains 18296 individuals. Of those, 15847 are individuals who were born in Sweden and 2449 who were born in another country. Information about 30 different variables was then matched for these individuals from RAMS, which is a register with annual data at Statistics Sweden. The data is based on administrative material, mainly from the tax agency. Information concerning the employment status of individuals for whom a match was found in 1999 was also added for 1998 and 2000.

The register that was used does not distinguish between individuals who are employed in a TEA and hired out and individuals who are employed as administrative personnel at a TEA. The second category, however, is probably only a small part of those employed by a TEA.

One drawback of the data is that we do not know which individuals actually work as temporarily hired out workers, and which work in the TEA administrating the activities. When studying the annual earnings for the group in the balanced panel we found

\footnotetext{
${ }^{9}$ See Fridén et al. (2000).
} 
individuals with a yearly income over 1 million SEK and individuals with no earnings even though they were coded as being employed. However, those with no earnings turned out to have income from self-employment. They were excluded from the study of the income development since it is reasonable to assume that they were owners of the temporary employment agencies. ${ }^{10} \mathrm{We}$ also excluded the individuals who had earnings over 1 million SEK. It is unlikely that these individuals worked as temporarily hired out employees. They were probably managers at a higher level in a TEA. These two restrictions led to that we excluded about 100 individuals.

\section{Self-employed}

We have identified the self-employed in the data set by using a variable representing "income from self-employment". The variable gives the total income from selfemployment in 1999. In 1999, 270953 individuals had such an income. To be counted as self-employed the individual should have at least 600 working hours in the year as selfemployed or self-employment should be the main activity. ${ }^{11}$ Only profits are included and not the wages paid out to the owner of a joint stock corporation. ${ }^{12}$

From the descriptive statistics is shown that some people have very low incomes from self-employment. It is probably explained by that it is possible to use losses from earlier years and to some extent also that it is possible for newly established firms to diminish the taxes to be paid by combining income and expenditures from different forms of employment. $^{13}$

We have made a further division of people identified as self-employed according to if they have earnings from another employer. The first group consists of those who only have had income from self-employment. Around 54 per cent, or 146,393 individuals, belong to this group. The second group consists of those who have had earnings from another employer, but for whom the income from self-employment is greater than the earnings. Around 15 per cent or 43,516 individuals belong to this group. Those two groups are included in the regressions estimated. Or formulated in another way, the main

\footnotetext{
${ }^{10}$ About 80 per cent of the TEA workplaces have between 1 and 50 employees and only 1.5 per cent have more than 500 employees.

${ }^{11}$ See SCB (1999).

12 See RSV (2003) and NUTEK (2003).

${ }^{13}$ See NUTEK (2003).
} 
definition of the self-employed is those who have a higher income from self-employment than from being an employee. The third and last group of self-employed include those who have higher earnings than income from self-employment. Around 30 per cent of all those with income from self-employment belong to this group.

\section{Who are the self-employed and those working in the temporary employment agencies?}

There are several different explanations for why people work in temporary employment agencies or are self-employed. It is explained by supply side factors if the employment form is preferred by the individual compared to a traditional job, also if he/she can get a traditional job in the labour market. A person can choose to work in a temporary employment agency because it gives higher flexibility regarding working hours, more varied job tasks and in some cases also higher remuneration. A person can choose to be self-employed for the same reasons. On the other hand it could be mainly demand side determined - the individual may not get a "traditional" job for some reason. In such cases, self-employment and a job in a temporary employment agency may be a possibility of getting employment. A job in a temporary employment agency may also be a way to enter the ordinary labour market. It is not uncommon that a person is eventually employed by the company which first initially only hired him/her from a temporary employment agency.

We shall now examine the size and composition of the two groups compared to all employed. To do that, we start with descriptive statistics shown in Table 1a. A comparison of one variable at a time leads to problems with interpretation so we continue with the estimation of a number of models for the probability to be self-employed or work in a temporary employment agency. In most cases, the estimations are based on the sample for all employed in 1999, i.e. around 3.9 million individuals.

Table 1a. Descriptive statistics 
Of all employed, 0.47 per cent are employed in a temporary employment agency and 4.87 per cent are self-employed. As mentioned in section 2 on data, we use a relatively narrow definition of those self-employed. A wider definition would of course give a higher value. There are rather large differences between the three groups. We will now present the results variable for variable.

The figures in Table 1 show that the gender composition differs between the three groups. Among all employed, women constitute almost half (47.8 per cent). Among those employed by temporary employment agencies, women are in a clear majority (60.0 per cent) and among the self-employed an even clearer minority (30.7 per cent). A partial explanation for the low female share among the self-employed may be that the business is registered in the husband's name in the majority of the cases where both wife and husband are working in the company.

The differences are also large regarding the age structure. Those employed in temporary employment agencies have a lower average age (34.8 years) than all employed (41.1 years), but the self-employed a higher average age (45.6 years) than all employed. A comparison based on five-year-groups shows that those employed in temporary employment agencies are overrepresented compared to all employed in all age groups up to and including those aged 31-35 years. The self-employed, on the other hand, are overrepresented from the age group 36-40 years and older. That the self-employed are overrepresented among the older is not mainly explained by that the propensity to start one's own business increases with age (more than up to a certain age), but more by that self-employed leave the labour market at a higher age than employees.

Closely related to the differences in age distribution is that those working in a temporary employment agency are more often unmarried (27.3 per cent) and the self-employed more often married (58.2 per cent) than all employed (47.8 per cent).

A study of educational level of three groups gives a more complicated picture. The selfemployed are strongly over-represented in the two lowest educational groups, which may be explained by the high average age in this group. Those employed in temporary employment agencies are over-represented among those having a longer secondary education and shorter higher education, partially reflecting that most belong to cohorts 
where most have completed secondary education and many have continued to higher education. The self-employed have a lower educational level on average than both those employed by temporary employment agencies and all employed.

A comparison of the regional distribution also shows large differences. ${ }^{14}$ The share of those employed by the temporary employment agencies who are living in the big city areas is much higher (58.7 per cent) and the share of self-employed in the same areas is somewhat lower ( 32.3 per cent) than the share of all employed (34.3 per cent) living there.

In one respect the employed by temporary employment agencies and the self-employed are similar to each other compared to all employed. In both groups immigrants and especially immigrants from Asia are overrepresented compared to all employed. ${ }^{15,16} \mathrm{We}$ will return to this issue in more depth later but for now briefly give some information by comparing the composition according to industry for immigrant and native self-employed. See Table 1b.

Table $1 \mathrm{~b}$ shows not surprisingly that natives are overrepresented among farmers and also in the construction industry. ${ }^{17}$ The immigrants on the other hand are strongly overrepresented in retailing and especially in the hotel and restaurant industry. In the last mentioned industry the immigrants constitute a majority among the self-employed. The composition according to industry indicates that the immigrant overrepresentation may be higher in the future - the number of farmers will continue to decline.

\footnotetext{
${ }^{14}$ The big city regions are defined as Stockholm, Gothenburg and Malmoe. Municipalities belonging to the Stockholm metropolitan area are: Botkyrka, Danderyd, Ekerö, Haninge, Huddinge, Järfälla, Lidingö, Nacka, Salem, Sigtuna, Sollentuna, Solna, Stockholm, Sundbyberg, Tyresö, Täby, Upplands Bro, Upplands Väsby, Vallentuna, Vaxholm, Värmdö and Österåker. Municipalities belonging to the Gothenburg metropolitan area are: Ale, Gothenburg, Härryda, Kungsbacka, Kungälv, Lerum, Mölndal, Partille, Stenungsund, Tjörn and Öckerö. Municipalities belonging to the Malmoe metropolitan area are: Burlöv, Kävlinge, Lomma, Lund, Malmoe, Staffanstorp, Svedala, Trelleborg and Vellinge [SCB].

${ }^{15}$ For analyses on why immigrants are self-employed to such a high extent see Dohlman (2002) and Blume Jensen et al. (2003). See SPUR (2001) for results from a survey regarding why people work in temporary employment agencies.

${ }^{16}$ Large differences are also found in other countries regarding the extent to which people are employed in temporary employment agencies. In the US around 21 per cent of those employed in the temporary employment agencies are Black Americans compared to 12 per cent of all employed. See GAO (2000).

${ }^{17}$ See Najib (1999) for an analysis of self-employment among immigrants in Sweden.
} 
Table 1b. Self-employment according to industry

We mentioned earlier that around 30 per cent of those with an income from selfemployment had earnings larger than that income. ${ }^{18}$ Who belongs to that group of selfemployed? Are they mainly people with higher education and high earnings who complement their earnings with some consulting etc? Or are they mainly people who start with self-employment to compensate for low earnings? In an attempt to give some information we have divided the population according to the earnings received during the same year (1999). See Table 2.

Table 2. Descriptive statistics for self-employed with earnings higher than income from self-employment

When studying Table 2 it is important to remember that the earnings are higher than the income from self-employment for all those included. It means that those with earnings lower than 100000 SEK must have an even lower income from self-employment.

There are some clear differences between the four groups. The female share is much lower in the group with high earnings (17.9 per cent) than in the group with low earnings (49.0 per cent). The average age is more or less the same in the four groups, but we find that a higher share is 40 years and older in the group with the highest earnings. We can also see that the earnings are positively correlated with the educational level. In the lowest earnings group only 10.2 per cent have a higher education 3 years or over or a post-graduate education. The corresponding figure for the highest earnings group is 55.2 per cent. The Table also shows that the income from self-employment increases with earnings, but that may at least partially depend on how we have constructed the group nobody can have an income from self-employment higher than the earnings. The upper limit for income from self-employment differs between the groups.

\footnotetext{
${ }^{18}$ When Statistics Sweden defines self-employment, the income from self-employed is multiplied by a factor of 1.6. If the income enhanced in that way is equal to or larger than the earnings the individual is defined as self-employed. With this definition 8.3 per cent of the group should be classified as selfemployed. Of all with an income from self-employment, 73700 individuals or 27 per cent should be classified as wage-earners according to this definition.
} 
An interpretation of the results is that different sub-groups are included in the group who has higher earnings than income from self-employment. There is one mainly male group with high earnings and high education. There is another group, in most cases with low education, both men and women with both low earnings and low income from selfemployment.

The immigrants in the group are overrepresented among those with low earnings. This is especially so among immigrants from Asia. The immigrant share is lower in this group of self-employed (7.8 per cent) than among those self-employed in the focus for this study (13.8 per cent). ${ }^{19}$ It shows that among immigrants, self-employment is more often their main labour income than is the case among natives.

To study each variable separately may lead to wrong conclusions. To analyze the effect from different characteristics, we have made probit estimations with probability to be employed in a temporary employment agency or to be self-employed as the dependent variable. The results from these estimations are shown in Table $3 a$ and $3 b$.

The results from the probit estimations are consistent with the results from the descriptive statistics. For those who were born in another country than Sweden the probability is higher to work in a temporary employment agency and to be self-employed than for those who were born in Sweden. As the share of self-employed is considerably higher than the share who works in a temporary employment agency, the effects are larger for the first group. The probability of working in a temporary employment agency is 0.1 percentage unit higher for immigrants than for natives. The corresponding figure for selfemployment is 1.9 percentage units. For the different age groups we get the same type of results as in the descriptive statistics. For those under 41 years of age the probability to work in a temporary employment agency is higher than for those in the reference group (41-45 years) and for those over 45 the probability is lower. The conclusion is the opposite as regards self-employment. The differences between the reference group (41-45 years) and those aged 46- 50 years or 51-55 years are not significant, however.

\footnotetext{
${ }^{19}$ See Wadensjö and Orrje (2002) for similar results for Denmark, and also Andersson and Wadensjö (2004a) for a comparison of Denmark and Sweden.
} 
In the descriptive statistics we saw that 19 per cent of the self-employed and 43 per cent of those working in temporary employment agencies were living in the Stockholm area compared to 20 per cent of all employed. In spite of that, model 1 in Table $3 \mathrm{~b}$ shows that the probability to be self-employed is significantly higher for those living in Stockholm than for those living in other parts of the country (except Gothenburg and Malmoe).

In model 2 in the two tables, we control for where the immigrants were born. For immigrants from Asia we got a significant and large effect which is in line with the descriptive statistics in Table 1a. It is the case both for working in a temporary employment agency and for being self-employed. Also immigrants from Africa and South America have a significantly higher probability to work in a temporary employment agency compared to natives. An explanation could be the problems those groups have in establishing themselves on the Swedish labour market and that a job in a temporary employment agency may be a way into the labour market. ${ }^{20}$ For selfemployment we do not get the same effects. Immigrants from Africa are not significantly more often self-employed than natives, and immigrants from South America are underrepresented among the self-employed when other factors are kept constant. An explanation to the differences between immigrants from Asia, Africa and South America in this respect could be differences in traditions and experiences regarding selfemployment in their home countries.

In model 3 in the two tables, year of arrival is included instead of country of origin as explanatory variables. The results of the estimations indicate that it is immigrants who arrived in the period 1986-1993 who are most overrepresented among those with temporary agency work. Among the self-employed it also those who arrived in Sweden in 1986-1993 who are most overrepresented but also those who arrived in 1973-1985 and to some extent even those who arrived in 1994-1999 are overrepresented.

Table 3a. Marginal effects for the probability to work in a temporary employment agency in 1999 among those employed. Three models

${ }^{20}$ See Andersson and Wadensjö (2002) and Andersson and Wadensjö (2004). 
Table 3b. Marginal effects for the probability to be self-employed in 1999 among those employed. Three models

From the results presented above we can see that the large immigrant share, especially the large Asian immigrant share, is what is common for employment in temporary employment agencies and self-employment.

As the overrepresentation of immigrants in both sectors is the most interesting result, we are focusing on a comparison of immigrants and natives in the two sectors in the rest of the paper. We start with descriptive statistics for the two groups and the two types of employment.

In Table 4 information regarding the natives and immigrants in temporary employment agencies in 1999 is shown. The similarities are maybe more pronounced than the dissimilarities but there are some differences that are of interest. Both natives and immigrants employed in this industry live mainly in the big cities but the immigrants are even more overrepresented in those areas. The female share is lower among immigrants than among natives, and the immigrants are also somewhat older on average. Immigrants are also married (and also divorced) to a higher extent - a difference that is only partially explained by the difference in age. The immigrants are overrepresented both among those with higher education and those with the lowest education.

Table 4. Characteristics of natives and immigrants employed in a temporary employment agency in 1999

Table 5 shows the same information regarding the self-employed. The differences are larger regarding some variables for this group. A majority of the self-employed immigrants live in the big city areas compared to only 30 per cent of the natives. The native self-employed are considerably older and have lower educational levels on average 
than the immigrant self-employed. These differences mirror to a high extent that the native self-employed are older farmers. The female share is low among immigrant as well as native self-employed, in both cases around 30 per cent.

Table 5. Characteristics for native and immigrant self-employed in 1999

It could be of interest to compare the three groups of immigrants with each other - those employed in temporary employment agencies, the self-employed, and all employed immigrants. Table 6 gives the information for such a comparison.

Table 6. Characteristics of immigrants employed in temporary employment agencies, self-employed, and independent of form of employment in 1999

Table 6 shows that the pattern is more or less the same as shown in Table 1 for all irrespective of origin. One example is that the female share in temporary employment agencies is higher and in self-employment lower than among all employed immigrants. In those age groups where immigrants are overrepresented among those working in temporary employment agencies they are underrepresented among the self-employed. A difference in comparison to Table 1 is that more than 50 per cent of immigrants live in the big cities among all the three different groups of employed. If a comparison is made according to country of origin, immigrants from Africa, South America and especially Asia are overrepresented among those employed in temporary employment agencies compared to all employed from the same areas. Among the self-employed the immigrants from Asia are highly overrepresented compared to their share among all employed. 


\section{Income from self-employment and from employment in a temporary employment agency}

We mentioned earlier that a job in a temporary employment agency and being selfemployed could be a choice preferred to a traditional job, but also be explained by that the possibilities of getting a traditional job are very small for some people. We are not able to analyze what characterizes the alternatives in detail here but will present some information regarding one result of employment, the yearly income.

We shall start by studying the incomes for those who are employed by a temporary employment agency. ${ }^{21}$ In Table 7 the income for immigrants and natives are compared. We see that the incomes are higher for natives than for immigrants, but also that the variations within each group are large. It should be underlined that we are not controlling for education and working hours.

Table 7. Yearly earnings for those employed in a temporary employment agency in 1999

The next step is to compare the incomes for the self-employed. Table 8a shows figures for native and immigrant self-employed. The natives have higher incomes also in this case, and we again stress that we are not controlling for characteristics as education or for working time. The incomes are low for all, natives and immigrants, but lowest for immigrants. It should also be noted that is complicated to compare income from selfemployment and earnings.

Table 8a. Yearly incomes for self-employed in 1999

\footnotetext{
${ }^{21}$ The annual income is the total income received by an individual from employers during a year. For employed in the temporary employment industry this means that we do not exactly know how much that has been received from an employer in this industry. If an individual during some part of the year, except for in November, were employed in a firm in another industry this income is also included in the variable we use. The annual income should rather be seen as the total income received by those who were employed in the TEI in November and not as the income received from an employment in this industry.
} 
In Table $8 \mathrm{~b}$ we compare the incomes according to industry and area of origin. The pattern found on the aggregate level is found also when looking at a more disaggregate level. Self-employed who were born in Sweden have higher incomes than immigrants with the exception for some industries for those born in the neighbouring Nordic countries. The incomes are especially low among immigrants born in Asia.

Table 8b. Yearly incomes for self-employed in 1999 according to country of origin and industry

The comparison of incomes carried out in this section shows that neither those employed in temporary employment agencies nor the self-employed have high incomes on average, even if there are those with very high incomes in both groups. Keeping in mind that it is difficult to compare incomes from self-employment with earnings, the results indicate that incomes from self-employment are generally low.

We have carried the analysis further by estimating income equations with log(income) as the dependent variable for those with temporary agency work and the self-employed. The results are shown in Tables 8 and 9.

Table 8 shows that immigrants who have temporary agency work have lower income than natives with the same type of work. The differences are large between different groups of immigrants. It also shows that women have lower income in the sector and that the incomes are higher in Stockholm than in other parts of the country.

Table 9 shows the corresponding results for the self-employed. The pattern is more or less the same but the values of the coefficients are larger. Immigrants and women have lower incomes from self-employment than natives and men, respectively. The incomes in Stockholm are much higher than those in other parts of the country. Note that the coefficient for second-generation immigrants is negative and significant. Also the second generation immigrants have lower incomes from self-employment than native Swedes. 


\section{Conclusions}

The forms of employment are changing over time. In this paper we have dealt with two types of employment - employment in a temporary employment agency and selfemployment. The number of people who work in temporary employment agencies has gradually increased during the last decade (since it became legal) and self-employment has changed - the number of farmers has dwindled and self-employment in other sectors has increased.

The composition of those working in the two sectors differs. Those employed in temporary employment agencies are often young, the majority is female, they live predominantly in the big city areas, and they have relatively high educations. The selfemployed are mainly men, are older, live mainly outside the big city areas and have relatively low educations in most cases. Common for the two groups is that immigrants are overrepresented, especially immigrants from Asia. Also common for the two groups is that they have some characteristics which are common among those with a weak position in the labour market (immigrant status, low education).

Immigrants with temporary agency work have lower incomes than natives in the same sector. This income difference between immigrants and natives is even more pronounced among the self-employed. Self-employed immigrants (both first and second generation) have much lower incomes than self-employed natives even if controlled for gender, age, region etc.

The results presented in this paper lead to a focus on the question why immigrants are overrepresented in two atypical forms of employment: self-employment and temporary agency work. Are these forms of employment preferred among immigrants due to larger possibilities to flexibility and independence, or are they chosen because of a lack of alternatives, i.e. instead of an employment as wage-earner? This is an important question which has to be investigated further. 


\section{References}

Affärsvärlden (2003), Konsultguiden, "I väntan på vändningen”.

Andersson, Pernilla and Wadensjö, Eskil (2002), "Vem arbetar i bemanningsbranschen?", Arbetsmarknad \& Arbetsliv, Vol. 8, pp. 257-271.

Andersson, Pernilla and Wadensjö, Eskil (2004), “Temporary employment agencies: A route for immigrants to enter the labour market?", IZA Discussion Paper 1090.

Andersson, Pernilla and Wadensjö, Eskil (2004a), "Self-employed immigrants in Denmark and Sweden: A way to economic self-reliance?”, IZA Discussion Paper 1130.

Autor, David H. (2000), "Outsourcing at Will: Unjust Dismissal Doctrine and the Growth of Temporary Help Employment”, Journal of Labour Economics, Vol. 21, pp 1-42.

Bager, Torben and Rezaei, Shahamek (2001), "Immigrant businesses in Denmark:

Captured in marginal business fields?", Centre for Small Business Research, University of Southern Denmark.

Bager, Torben and Rezaei, Shahamek (2001a), "Invandrervirksomheder i Danmark, Center for Småvirksomhedsforskning”, Syddansk Universitet.

Bemanningsföretagen (2004), Statistik 2003.

Blume Jensen, Kræn., Skyt Nielsen, Helena, Ejrnæs, Mette and Würtz, Allan (2003), “Self-Employment among Immigrants: A Last Resort?” in Kræn Blume, Integration of Immigrants in Danish Labour Market, Ph.D. thesis, Aarhus School of Business, Department of Economics.

Dohlmann, Cecile (2001), "Self-employment among male immigrants in Denmark. Long term unemployment and comparative advantages", Working Paper 08:2001, The Danish National Institute of Social Research.

Friberg, Kent, Olli, Åsa and Wadensjö, Eskil (1999), Privat förmedling av arbete $i$ Sverige, Swedish Institute for Social Research, Stockholm University, Stockholm. 
Fridén, Lennart, Hedén, Ylva and Eskil Wadensjö (2000), "Personaluthyrningsföretag en bro till arbetsmarknaden?” Bilaga 2 till Mångfaldsprojektet.

GAO (United States General Accounting Office) (2000), Contingent Workers. Incomes and benefits lag behind those of the rest of the workforce, GAO/HEHS-00-76, June

Golden, Lonnie (1996), “The Expansion of Temporary Help Employment in the U.S., 1982-1992: A Test of Alternative Explanations”, Applied Economics, Vol. 28, pp. $1127-41$.

Houseman, Susan N. (1997), "Temporary, Part-Time, and Contract Employment in the United States: A Report on the W.E. Upjohn Institute's Employer Survey on Flexible Staffing Policies", June.

Miles, Thomas J. (2000), “Common Law Exceptions to Employment at Will and U.S. Labor Markets", The Journal of Law, Economics \& Organization, Vol. 16, pp. 74101.

Milner, Joseph M. and Pinker, Edieal J. (2001), ”Contingent Labor Contracting under Demand and Supply Uncertainty", Management Science, Vol. 47, pp. 1046-1062.

Najib, Ali B. (1999), Myten om invandrarföretaget, Svenska EU Programkontoret, NUTEK.

NUTEK (2003), Startlinjen, www.nutek.se/index.jsp , 2003-04-23

RSV (2003), Att deklarera näringsverksamhet, www.rsv.se , 2003-04-23

SCB (1999), Registerbaserad arbetsmarknadsstatistik.

SPUR (2001), Personalstudie 2001.

Storrie, Donald (2002), "Temporary agency work in the European Union”, European Foundation for the Improvement of Living and Working Conditions, Dublin. Wadensjö, Eskil \& Helena Orrje (2002), "Immigrants and self-employment in Denmark", Paper presented at the EALE conference in Paris, September 2002. 
Table 1a. Descriptive statistics

\begin{tabular}{|c|c|c|c|}
\hline Variables & $\begin{array}{l}\text { Employed by a } \\
\text { temporary employment } \\
\text { agency in } 1999\end{array}$ & $\begin{array}{l}\text { Self-employed } \\
\text { in } 1999^{*}\end{array}$ & $\begin{array}{l}\text { All employed 16-64 } \\
\text { years of age in } 1999\end{array}$ \\
\hline Woman & $60.0 \%$ & $30.7 \%$ & $47.8 \%$ \\
\hline Average age & 34.8 years & 45.6 years & 41.1 years \\
\hline \multicolumn{4}{|l|}{ Age groups } \\
\hline $16-20$ & $7.4 \%$ & $0.4 \%$ & $3.1 \%$ \\
\hline $21-25$ & $20.3 \%$ & $2.6 \%$ & $8.0 \%$ \\
\hline $26-30$ & $16.6 \%$ & $6.4 \%$ & $11.4 \%$ \\
\hline $31-35$ & $14.6 \%$ & $10.9 \%$ & $13.3 \%$ \\
\hline $36-40$ & $10.5 \%$ & $13.1 \%$ & $12.2 \%$ \\
\hline $41-45$ & $8.7 \%$ & $14.0 \%$ & $12.4 \%$ \\
\hline $46-50$ & $8.4 \%$ & $15.1 \%$ & $12.8 \%$ \\
\hline $51-55$ & $7.9 \%$ & $16.8 \%$ & $13.8 \%$ \\
\hline $56-60$ & $4.5 \%$ & $12.9 \%$ & $9.4 \%$ \\
\hline $61-65$ & $1.2 \%$ & $7.6 \%$ & $3.6 \%$ \\
\hline Born in Sweden & $86.7 \%$ & $86.2 \%$ & $90.5 \%$ \\
\hline \multicolumn{4}{|l|}{ Foreign born } \\
\hline Nordic countries & $3.0 \%$ & $3.0 \%$ & $3.4 \%$ \\
\hline EU12* & $1.0 \%$ & $1.6 \%$ & $1.0 \%$ \\
\hline Other European countries & $2.6 \%$ & $2.4 \%$ & $2.0 \%$ \\
\hline Africa & $0.9 \%$ & $0.4 \%$ & $0.4 \%$ \\
\hline North America & $0.3 \%$ & $0.2 \%$ & $0.2 \%$ \\
\hline South America & $1.2 \%$ & $0.3 \%$ & $0.5 \%$ \\
\hline Asia & $4.0 \%$ & $5.6 \%$ & $1.9 \%$ \\
\hline Oceania & $0.0 \%$ & $0.0 \%$ & $0.0 \%$ \\
\hline Soviet Union & $0.2 \%$ & $0.1 \%$ & $0.1 \%$ \\
\hline All & $13.4 \%$ & $13.8 \%$ & $9.7 \%$ \\
\hline $\begin{array}{l}\text { Born in Sweden, both parents born } \\
\text { in another country }\end{array}$ & $4.5 \%$ & $2.8 \%$ & $3.0 \%$ \\
\hline $\begin{array}{l}\text { Born in Sweden, one parent foreign } \\
\text { born }\end{array}$ & $11.2 \%$ & $10.3 \%$ & $10.1 \%$ \\
\hline \multicolumn{4}{|l|}{ Year of immigration } \\
\hline $1936-1965$ & $6.7 \%$ & $12.2 \%$ & $14.2 \%$ \\
\hline $1966-1972$ & $12.8 \%$ & $14.2 \%$ & $17.1 \%$ \\
\hline $1973-1985$ & $31.2 \%$ & $32.9 \%$ & $28.6 \%$ \\
\hline $1986-1993$ & $35.3 \%$ & $32.2 \%$ & $25.3 \%$ \\
\hline 1994-1999 & $14.0 \%$ & $8.5 \%$ & $14.8 \%$ \\
\hline Number of observations & 2422 & 26159 & 371211 \\
\hline \multicolumn{4}{|l|}{ Highest educational level } \\
\hline Primary school less than 9 years & $4.1 \%$ & $15.8 \%$ & $7.5 \%$ \\
\hline Primary school $9(10)$ years & $14.3 \%$ & $16.4 \%$ & $12.4 \%$ \\
\hline
\end{tabular}


Upper secondary 2 years or less

Upper secondary 2 years or more

Higher education less than 3 years

Higher education 3 years or more

$9.9 \%$

$7.4 \%$

$13.6 \%$

Post-graduate education

Resides in a large city in 1999

$58.7 \%$

$32.3 \%$

$34.3 \%$

Stockholm

$43.0 \%$

$19.2 \%$

$20.2 \%$

Gothenburg

$11.6 \%$

$7.7 \%$

$8.6 \%$

Malmoe

$4.1 \%$

$5.4 \%$

$5.5 \%$

\section{Marital status}

Married

$27.3 \%$

$58.2 \%$

$47.8 \%$

Unmarried

$60.9 \%$

$11.7 \%$

$40.4 \%$

Divorced

Share self-employed and employed

in a TEA of all employed natives

Share self-employed and employed

in a TEA of all employed

immigrants

\begin{tabular}{|c|c|c|c|}
\hline Number of observations & 18296 & 189909 & $\begin{array}{c}3898991 \\
(3906861)\end{array}$ \\
\hline
\end{tabular}

Notes: Immigrants born in Oceania constitute $0.03 \%$ and immigrants born in Soviet Union constitute $0.06 \%$.

* Self-employed are defined as those who have an income from self-employment higher than that from being employed.

**The descriptive statistics are based on 3898991 individuals. Some regressions are based on that number of

observations, some on the lower numbers indicated within parentheses. The difference depends on if the variable Year of immigration is included or not. If that variable is included, 7870 immigrants for which information on Year of immigration is lacking are excluded. 
Table 1b. Self-employment according to industry

\begin{tabular}{llll}
\hline Industry & All & Natives & Immigrants \\
\hline Agriculture, hunting, forestry, fishing & $18.9 \%$ & $21.6 \%$ & $2.0 \%$ \\
Manufacturing & $5.4 \%$ & $5.5 \%$ & $4.6 \%$ \\
Construction & $9.8 \%$ & $10.7 \%$ & $4.3 \%$ \\
Retailing & $12.9 \%$ & $11.9 \%$ & $19.5 \%$ \\
Hotel and restaurants & $3.7 \%$ & $1.6 \%$ & $16.7 \%$ \\
Transport, storage and communication & $6.7 \%$ & $6.5 \%$ & $8.0 \%$ \\
Financial services & $0.1 \%$ & $0.1 \%$ & $0.0 \%$ \\
Industrial services & $12.0 \%$ & $12.3 \%$ & $10.4 \%$ \\
Education & $0.6 \%$ & $0.6 \%$ & $0.4 \%$ \\
Health and social services & $2.4 \%$ & $2.4 \%$ & $2.5 \%$ \\
Other social and private services & $8.8 \%$ & $8.9 \%$ & $8.5 \%$ \\
\hline Number of observations & 189909 & 163750 & 26159 \\
\hline
\end{tabular}

Note: The classification according to industry follows Statistics Sweden's SNI classification. Some sectors with less than 0.05 per cent of the self-employed are excluded from this table. 
Table 2. Descriptive statistics for self-employed with earnings higher than income from selfemployment

\begin{tabular}{|c|c|c|c|c|}
\hline Variables & $\begin{array}{l}\text { Yearly earnings } \\
\text { less than } 100000 \\
\text { SEK }\end{array}$ & $\begin{array}{l}\text { Yearly earnings more than } \\
100000 \text { SEK, less than } 200 \\
000 \text { SEK }\end{array}$ & $\begin{array}{l}\text { Yearly earnings more than } \\
200000 \text { SEK, less than } \\
300000 \text { SEK }\end{array}$ & $\begin{array}{l}\text { Yearly earnings } \\
\text { more than } \\
300000 \text { SEK }\end{array}$ \\
\hline $\begin{array}{l}\text { Income from self employment } \\
\text { (standard deviations in parentheses) }\end{array}$ & $18499(199981)$ & $29834(33421)$ & $22760(34175)$ & $31099(56496)$ \\
\hline Woman & $49.0 \%$ & $48.7 \%$ & $28.6 \%$ & $17.9 \%$ \\
\hline Average age (years) & 42.3 & 43.8 & 44.4 & 46.4 \\
\hline \multicolumn{5}{|l|}{ Age groups } \\
\hline $16-20$ years & $2.1 \%$ & $0.3 \%$ & $0.0 \%$ & $0.0 \%$ \\
\hline $21-25$ years & $7.1 \%$ & $3.4 \%$ & $1.8 \%$ & $0.3 \%$ \\
\hline $26-30$ years & $10.2 \%$ & $7.8 \%$ & $7.1 \%$ & $3.5 \%$ \\
\hline $31-35$ years & $13.1 \%$ & $12.0 \%$ & $11.8 \%$ & $9.6 \%$ \\
\hline $36-40$ years & $12.9 \%$ & $14.5 \%$ & $13.7 \%$ & $12.9 \%$ \\
\hline $41-45$ years & $12.5 \%$ & $16.4 \%$ & $17.1 \%$ & $17.4 \%$ \\
\hline $46-50$ years & $12.7 \%$ & $15.9 \%$ & $18.2 \%$ & $20.1 \%$ \\
\hline $51-55$ years & $12.6 \%$ & $15.3 \%$ & $17.9 \%$ & $21.0 \%$ \\
\hline $56-60$ years & $10.5 \%$ & $10.6 \%$ & $9.4 \%$ & $11.6 \%$ \\
\hline $61-65$ years & $6.2 \%$ & $3.8 \%$ & $2.3 \%$ & $3.7 \%$ \\
\hline \multicolumn{5}{|l|}{ Country of origin } \\
\hline Sweden & $89.5 \%$ & $93.0 \%$ & $93.2 \%$ & $92.8 \%$ \\
\hline Nordic countries (except Sweden) & $2.5 \%$ & $2.3 \%$ & $2.5 \%$ & $2.3 \%$ \\
\hline EU & $1.3 \%$ & $1.2 \%$ & $1.2 \%$ & $1.5 \%$ \\
\hline Other European countries & $1.9 \%$ & $1.4 \%$ & $1.4 \%$ & $1.6 \%$ \\
\hline Africa & $0.4 \%$ & $0.2 \%$ & $0.2 \%$ & $0.2 \%$ \\
\hline North America & $0.4 \%$ & $0.2 \%$ & $0.2 \%$ & $0.3 \%$ \\
\hline South America & $0.4 \%$ & $0.3 \%$ & $0.2 \%$ & $0.2 \%$ \\
\hline Asia & $3.4 \%$ & $1.4 \%$ & $0.9 \%$ & $0.9 \%$ \\
\hline Oceania & $0.0 \%$ & $0.0 \%$ & $0.0 \%$ & $0.0 \%$ \\
\hline Soviet Union & $0.0 \%$ & $0.0 \%$ & $0.1 \%$ & $0.1 \%$ \\
\hline Sweden, both parents foreign born & $2.7 \%$ & $2.3 \%$ & $2.2 \%$ & $2.5 \%$ \\
\hline Sweden, one parent foreign born & $10.2 \%$ & $9.8 \%$ & $9.6 \%$ & $10.8 \%$ \\
\hline \multicolumn{5}{|l|}{ Year of immigration } \\
\hline $1945-1965$ & $10.5 \%$ & $16.0 \%$ & $17.1 \%$ & $18.6 \%$ \\
\hline $1966-1972$ & $13.7 \%$ & $19.6 \%$ & $26.0 \%$ & $21.3 \%$ \\
\hline 1973-1985 & $32.5 \%$ & $34.9 \%$ & $35.9 \%$ & $37.1 \%$ \\
\hline $1986-1993$ & $32.4 \%$ & $23.4 \%$ & $17.3 \%$ & $17.9 \%$ \\
\hline $1994-1999$ & $10.8 \%$ & $6.1 \%$ & $3.7 \%$ & $5.0 \%$ \\
\hline Number of observations (this variable) & 1911 & 1901 & 1505 & 914 \\
\hline \multicolumn{5}{|l|}{ Highest educational level } \\
\hline Primary school less than 9 years & $9.5 \%$ & $8.4 \%$ & $6.2 \%$ & $1.6 \%$ \\
\hline Primary school $9(10)$ years & $13.7 \%$ & $12.3 \%$ & $9.4 \%$ & $3.5 \%$ \\
\hline Upper secondary 2 years or less & $32.7 \%$ & $36.4 \%$ & $25.9 \%$ & $10.0 \%$ \\
\hline Upper secondary 2 years or more & $18.1 \%$ & $14.2 \%$ & $14.7 \%$ & $12.1 \%$ \\
\hline Higher education less than 3 years & $15.3 \%$ & $15.3 \%$ & $18.5 \%$ & $17.4 \%$ \\
\hline Higher education 3 years or more & $9.9 \%$ & $12.5 \%$ & $23.5 \%$ & $41.5 \%$ \\
\hline Post-graduate education & $0.3 \%$ & $0.6 \%$ & $1.5 \%$ & $13.7 \%$ \\
\hline Resides in a large city in 1999 & $31.3 \%$ & $29.6 \%$ & $34.6 \%$ & $51.1 \%$ \\
\hline Stockholm & $18.6 \%$ & $16.9 \%$ & $19.6 \%$ & $31.6 \%$ \\
\hline Gothenburg & $7.7 \%$ & $7.5 \%$ & $9.2 \%$ & $12.1 \%$ \\
\hline Malmoe & $5.0 \%$ & $5.1 \%$ & $5.8 \%$ & $7.4 \%$ \\
\hline \multicolumn{5}{|l|}{ Marital status } \\
\hline Married & $53.9 \%$ & $62.1 \%$ & $60.6 \%$ & $68.2 \%$ \\
\hline Unmarried & $35.5 \%$ & $28.3 \%$ & $28.1 \%$ & $19.1 \%$ \\
\hline Divorced & $9.7 \%$ & $8.7 \%$ & $10.6 \%$ & $12.1 \%$ \\
\hline Number of observations & 18223 & 27236 & 22244 & 12628 \\
\hline
\end{tabular}


Table 3a. Marginal effects for the probability to work in a temporary employment agency in 1999 among those employed. Three models

\begin{tabular}{|c|c|c|c|}
\hline Variables & Model 1 & Model 2 & Model 3 \\
\hline \multicolumn{4}{|l|}{ Gender } \\
\hline Woman & $0.0018(0.00006)^{* *}$ & $0.0019(0.00006)^{* *}$ & $0.0018(0.00006) * *$ \\
\hline \multicolumn{4}{|l|}{ Country of origin } \\
\hline Sweden & reference & reference & reference \\
\hline Foreign born & $0.0012(0.00010)^{* *}$ & - & - \\
\hline $\begin{array}{l}\text { Born in Sweden with both parents born in another } \\
\text { country }\end{array}$ & $0.0008(0.00016)^{* *}$ & $0.0008(0.00016)^{* *}$ & $0.0008(0.00016)^{* *}$ \\
\hline Born in Sweden with one parent born in another country & $0.0006(0.00010)^{* *}$ & $0.0006(0.00010)^{* *}$ & $0.0006(0.00010) * *$ \\
\hline Nordic countries & - & $-0.0000(0.00015)$ & - \\
\hline EU & - & $0.0004(0.00029)$ & - \\
\hline Other European countries & - & $0.0016(0.00024)^{* *}$ & - \\
\hline Africa & - & $0.0015(0.0004)^{* *}$ & - \\
\hline North America & - & $0.0019(0.00069) * *$ & - \\
\hline South America & - & $0.0017(0.00039)^{* *}$ & - \\
\hline Asia & - & $0.0026(0.00024) * *$ & - \\
\hline Oceania & - & $-0.0025(0.00069)$ & - \\
\hline Soviet Union & - & $0.0053(0.00174)^{* *}$ & - \\
\hline \multicolumn{4}{|l|}{ Year of immigration } \\
\hline $1936-1965$ & - & - & $-0.0000(0.00028)$ \\
\hline 1966-1972 & - & - & $0.0008(0.00025)^{* *}$ \\
\hline $1973-1985$ & - & - & $0.0008(0.00017)^{* *}$ \\
\hline 1986-1993 & - & - & $0.0024(0.00022) * *$ \\
\hline 1994-1999 & - & - & $0.0008(0.00025)^{* *}$ \\
\hline Highest educational level & & - & \\
\hline Primary school less than 9 years & $-0.0002(0.00014)$ & $-0.0002(0.00014)$ & $-0.0002(0.00014)$ \\
\hline Primary school $9(10)$ years & $-0.0003(0.00009)^{* *}$ & $-0.0003(0.00008)^{* *}$ & $-0.0003(0.00008)^{* *}$ \\
\hline Upper secondary 2 years or less & $-0.0009(0.00007)^{* *}$ & $-0.0009(0.00007)^{* *}$ & $-0.0009(0.00007)^{* *}$ \\
\hline Upper secondary 2 years or more & reference & reference & reference \\
\hline Higher education less than 3 years & $-0.0007(0.00008)^{* *}$ & $-0.0007(0.00008)^{* *}$ & $-0.0007(0.00008)^{* *}$ \\
\hline Higher education 3 years or more & $-0.0015(0.00007)^{* *}$ & $-0.0015(0.00007)^{* *}$ & $-0.0015(0.00007)^{* *}$ \\
\hline Post-graduate education & $-0.0031(0.00009)^{* *}$ & $-0.0031(0.00009)^{* *}$ & $-0.0031(0.00009)^{* *}$ \\
\hline \multicolumn{4}{|l|}{ Resides in a large city } \\
\hline Stockholm & $0.0054(0.00011)^{* *}$ & $0.0054(0.00011)^{* *}$ & $0.0054(0.00011)^{* *}$ \\
\hline Gothenburg & $0.0027(0.00015)^{* *}$ & $0.0027(0.00014)^{* *}$ & $0.0027(0.00015)^{* *}$ \\
\hline Malmoe & $0.0003(0.00013)^{*}$ & $0.0002(0.00013)^{*}$ & $0.0003(0.00013)^{*}$ \\
\hline \multicolumn{4}{|l|}{ Age groups } \\
\hline $16-20$ years & $0.0048(0.00032)^{* *}$ & $0.0046(0.00031)^{* *}$ & $0.0047(0.00032)^{* *}$ \\
\hline $21-25$ years & $0.0054(0.00026)^{* *}$ & $0.0052(0.00025)^{* *}$ & $0.0053(0.00026)^{* *}$ \\
\hline $26-30$ years & $0.0023(0.00017)^{* *}$ & $0.0022(0.00017)^{* *}$ & $0.0023(0.00017)^{* *}$ \\
\hline $31-35$ years & $0.0014(0.00014)^{* *}$ & $0.0013(0.00014)^{* *}$ & $0.0013(0.00014) * *$ \\
\hline $36-40$ years & $0.0005(0.00013)^{* *}$ & $0.0005(0.00013)^{* *}$ & $0.0005(0.00013)^{* *}$ \\
\hline $41-45$ years & reference & reference & reference \\
\hline $46-50$ years & $-0.0001(0.00012)$ & $-0.0001(0.00012)$ & $-0.0001(0.00012)$ \\
\hline $51-55$ years & $-0.0006(0.00011)^{* *}$ & $-0.0005(0.00011)^{* *}$ & $-0.0005(0.00011) * *$ \\
\hline $56-60$ years & $-0.0011(0.00011)^{* *}$ & $-0.0010(0.00011)^{* *}$ & $-0.0010(0.00011)^{* *}$ \\
\hline $61-65$ years & $-0.0019(0.00012)^{* *}$ & $-0.0018(0.00013)^{* *}$ & $-0.0018(0.00013)^{* *}$ \\
\hline \multicolumn{4}{|l|}{ Marital status } \\
\hline Unmarried & reference & reference & reference \\
\hline Married & $-0.0014(0.00007)^{* *}$ & $-0.0015(0.00007)^{* *}$ & $-0.0014(0.00007)^{* *}$ \\
\hline Divorced & $0.0005(0.00011)^{* *}$ & $0.0004(0.00011)^{* *}$ & $0.0005(0.00011)^{* *}$ \\
\hline Number of observations & 3906498 & 3906498 & 3897743 \\
\hline
\end{tabular}

Notes: $*=$ significant on the $5 \%$ level, $* *=$ significant on the $1 \%$ level; standard errors within parentheses. 
Table 3b. Marginal effects for the probability to be self-employed in 1999 among those employed. Three models

\begin{tabular}{|c|c|c|c|}
\hline Variables & Model 1 & Model 2 & Model 3 \\
\hline Woman & $-0.0286(0.0002)^{* *}$ & $-0.0277(0.0002)^{* *}$ & $-0.284(0.0002)^{* *}$ \\
\hline \multicolumn{4}{|l|}{ Country of origin } \\
\hline Sweden with parents born in Sweden & reference & reference & reference \\
\hline Foreign born & $0.0186(0.0004)^{* *}$ & $*$ & $*$ \\
\hline Nordic countries (except Sweden) & $*$ & $-0.0080(0.0005)^{* *}$ & \\
\hline EU & $*$ & $0.0216(0.0011)^{* *}$ & \\
\hline Other European countries & $*$ & $0.0122(0.0008) * *$ & \\
\hline Africa & $*$ & $0.0007(0.0014)$ & \\
\hline North America & $*$ & $0.0210(0.0027)^{* *}$ & \\
\hline South America & $*$ & $-0.0151(0.0011)^{* *}$ & \\
\hline Asia & $*$ & $0.0986(0.0013)^{* *}$ & \\
\hline Oceania & $*$ & $0.0269(0.0075) * *$ & \\
\hline Soviet Union & $*$ & $0.0378(0.0060)^{* *}$ & \\
\hline $\begin{array}{l}\text { Born in Sweden with parents born in } \\
\text { another country }\end{array}$ & $0.0010(0.0006)$ & $0.0011(0.0006)^{*}$ & $0.0010(0.0006)$ \\
\hline $\begin{array}{l}\text { Born in Sweden with one parent born in } \\
\text { another country }\end{array}$ & $-0.0006(0.003)$ & $-0.0008(0.0003)^{*}$ & $-0.0008(0.0003)^{*}$ \\
\hline \multicolumn{4}{|l|}{ Year of immigration } \\
\hline $1936-1965$ & $*$ & $*$ & $-0.0048(0.0007)^{* *}$ \\
\hline 1966-1972 & $*$ & $*$ & $0.0019(0.0007)^{* *}$ \\
\hline $1973-1985$ & $*$ & $*$ & $0.0297(0.0008)^{* *}$ \\
\hline 1986-1993 & $*$ & $*$ & $0.0426(0.0009)^{* *}$ \\
\hline 1994-1999 & $*$ & $*$ & $0.0111(0.0011)^{* *}$ \\
\hline Highest educational level & $*$ & & \\
\hline Primary school less than 9 years & $0.0131(0005)^{* *}$ & $0.0119(0.0005)^{* *}$ & $0.0125(0.0005)^{* *}$ \\
\hline Primary school $9(10)$ years & $0.0078(0.0004)^{* *}$ & $0.0077(0.0004)^{* *}$ & $0.0078(0.0004)^{* *}$ \\
\hline Upper secondary 2 years or less & $-0.0061(0.0003)^{* *}$ & $-0.0055(0.0003)^{* *}$ & $-0.0057(0.0003) * *$ \\
\hline Upper secondary 2 years or more & reference & reference & reference \\
\hline Higher education less than 3 years & $-0.0208(0.0003)^{* *}$ & $-0.0206(0.00026)^{* *}$ & $-0.0207(0.0003) * *$ \\
\hline Higher education 3 years or more & $-0.0268(0.0002)^{* *}$ & $-0.0267(0.0002)^{* *}$ & $-0.0269(0.0002)^{* *}$ \\
\hline Post-graduate education & $-0.0336(0.0003)^{* *}$ & $-0.0335(0.0003)^{* *}$ & $-0.0336(0.0003)^{* *}$ \\
\hline \multicolumn{4}{|l|}{ Resides in a large city } \\
\hline Stockholm & $0.0029(0.0003)^{* *}$ & $0.0022(0.0003)^{* *}$ & $0.0025(0.0003)^{* *}$ \\
\hline Gothenburg & $-0.0016(0.0004)^{* *}$ & $-0.0023(0.0003)^{* *}$ & $-0.0018(0.0003)^{* *}$ \\
\hline Malmoe & $0.0013(0.0004)^{* *}$ & $0.0008(0.0004)^{*}$ & $0.0010(0.0004)^{*}$ \\
\hline \multicolumn{4}{|l|}{ Age groups } \\
\hline $16-20$ years & $-0.0389(0.0002)^{* *}$ & $-0.0387(0.0002)^{* *}$ & $-0.0389(0.0002) * *$ \\
\hline $21-25$ years & $-0.0326(0.0002)^{* *}$ & $-0.0331(0.0002)^{* *}$ & $-0.0327(0.0002) * *$ \\
\hline $26-30$ years & $-0.0210(0.0003)^{* *}$ & $-0.0219(0.0003)^{* *}$ & $-0.0212(0.0003)^{* *}$ \\
\hline $31-35$ years & $-0.0111(0.0003)^{* *}$ & $-0.0117(0.0003)^{* *}$ & $-0.0113(0.0003)^{* *}$ \\
\hline $36-40$ years & $-0.0018(0.0004)^{* *}$ & $-0.0025(0.0003)^{* *}$ & $-0.0020(0.0004) * *$ \\
\hline $41-45$ years & reference & reference & reference \\
\hline $46-50$ years & $0.0009(0.0004)$ & $0.0019(0.004)^{* *}$ & $0.0016(0.0004)^{* *}$ \\
\hline $51-55$ years & $0.0004(0.0004)$ & $0.0021(0.0004)^{* *}$ & $0.0019(0.0004)^{* *}$ \\
\hline $56-60$ years & $0.0036(0.0004)^{* *}$ & $0.0055(0.0004)^{* *}$ & $0.0057(0.0004)^{* *}$ \\
\hline $61-65$ years & $0.0274(0.0007)^{* *}$ & $0.0300(0.0007)^{* *}$ & $0.0310(0.0008)^{* *}$ \\
\hline \multicolumn{4}{|l|}{ Marital status } \\
\hline Unmarried & reference & reference & reference \\
\hline Married & $0.0069(0.0002)^{* *}$ & $0.0051(0.0002)^{* *}$ & $0.0062(0.0002)^{* *}$ \\
\hline Divorced & $0.0005(0.0004)$ & $-0.0005(0.0003)$ & $-0.0003(0.0004)$ \\
\hline Number of observations & 3898091 & 3898091 & 3898089 \\
\hline
\end{tabular}

Notes: $*=$ significant on the $5 \%$ level, $* *=$ significant on the $1 \%$ level; standard errors within parentheses. 
Table 4. Employed in temporary employment agencies and self-employed.

\begin{tabular}{|c|c|c|c|c|}
\hline \multirow[b]{2}{*}{ Variables } & \multicolumn{2}{|c|}{$\begin{array}{c}\text { Employed in a temporary } \\
\text { employment agency in } \\
1999\end{array}$} & \multicolumn{2}{|c|}{ Self-employed in 1999} \\
\hline & Natives & Immigrants & Natives & Immigrants \\
\hline Woman & $61.1 \%$ & $53.3 \%$ & $30.9 \%$ & $29.6 \%$ \\
\hline Average age & 34.5 & 36.3 & 46.0 & $42.6 \%$ \\
\hline \multicolumn{5}{|l|}{ Age groups } \\
\hline $16-20$ years & $7.9 \%$ & $4.5 \%$ & $0.4 \%$ & $0.5 \%$ \\
\hline $21-25$ years & $20.9 \%$ & $16.4 \%$ & $2.5 \%$ & $3.5 \%$ \\
\hline $26-30$ years & $16.8 \%$ & $15.1 \%$ & $6.0 \%$ & $8.5 \%$ \\
\hline $31-35$ years & $14.4 \%$ & $15.9 \%$ & $10.5 \%$ & $13.8 \%$ \\
\hline $36-40$ years & $10.1 \%$ & $12.7 \%$ & $12.4 \%$ & $17.6 \%$ \\
\hline $41-45$ years & $8.3 \%$ & $11.5 \%$ & $13.6 \%$ & $16.9 \%$ \\
\hline $46-50$ years & $8.0 \%$ & $10.8 \%$ & $15.1 \%$ & $15.0 \%$ \\
\hline $51-55$ years & $7.9 \%$ & $7.7 \%$ & $17.6 \%$ & $12.0 \%$ \\
\hline $56-60$ years & $4.6 \%$ & $4.0 \%$ & $13.7 \%$ & $8.2 \%$ \\
\hline $61-65$ years & $1.1 \%$ & $1.4 \%$ & $8.2 \%$ & $3.9 \%$ \\
\hline \multicolumn{5}{|l|}{ Highest educational level } \\
\hline Primary school less than 9 years & $3.5 \%$ & $7.4 \%$ & $16.2 \%$ & $13.2 \%$ \\
\hline Primary school $9(10)$ years & $14.4 \%$ & $13.8 \%$ & $16.4 \%$ & $16.6 \%$ \\
\hline Upper secondary 2 years or less & $26.0 \%$ & $21.8 \%$ & $34.3 \%$ & $24.5 \%$ \\
\hline Upper secondary 2 years or more & $30.1 \%$ & $27.6 \%$ & $16.5 \%$ & $19.8 \%$ \\
\hline Higher education less than 3 years & $16.2 \%$ & $15.9 \%$ & $9.3 \%$ & $10.6 \%$ \\
\hline Higher education 3 years or more & $9.5 \%$ & $12.1 \%$ & $6.7 \%$ & $11.3 \%$ \\
\hline Post-graduate education & $0.0 \%$ & $0.3 \%$ & $0.2 \%$ & $0.7 \%$ \\
\hline Resides in a large city & $57.8 \%$ & $64.1 \%$ & $29.0 \%$ & $52.8 \%$ \\
\hline Stockholm & $42.2 \%$ & $48.2 \%$ & $16.9 \%$ & $34.0 \%$ \\
\hline Gothenburg & $11.4 \%$ & $12.7 \%$ & $7.2 \%$ & $10.8 \%$ \\
\hline Malmoe & $4.2 \%$ & $3.2 \%$ & $4.9 \%$ & $8.0 \%$ \\
\hline \multicolumn{5}{|l|}{ Marital status } \\
\hline Married & $25.4 \%$ & $41.4 \%$ & $57.0 \%$ & $65.3 \%$ \\
\hline Unmarried & $64.0 \%$ & $43.0 \%$ & $30.8 \%$ & $17.9 \%$ \\
\hline Divorced & $10.6 \%$ & $15.6 \%$ & $11.1 \%$ & $16.0 \%$ \\
\hline $\begin{array}{l}\text { Born in Sweden with parents born } \\
\text { in another country }\end{array}$ & $4.5 \%$ & & $3.2 \%$ & \\
\hline $\begin{array}{l}\text { Born in Sweden with one parent } \\
\text { born in another country }\end{array}$ & $11.2 \%$ & & $11.9 \%$ & \\
\hline Number of observations & 15847 & 2422 & 163750 & 26159 \\
\hline
\end{tabular}


Table 5. Characteristics of immigrants employed in temporary employment agencies, self-employed, and independent of form of employment in 1999

\begin{tabular}{|c|c|c|c|}
\hline Variables & $\begin{array}{l}\text { Employed in a temporary } \\
\text { employment agency }\end{array}$ & Self-employed & All employed \\
\hline Woman & $53.5 \%$ & $29.6 \%$ & $48.5 \%$ \\
\hline Average age (years) & 36.4 & 42.6 & 41.8 \\
\hline \multicolumn{4}{|l|}{ Age groups } \\
\hline $16-20$ years & $4.4 \%$ & $0.5 \%$ & $1.8 \%$ \\
\hline $21-25$ years & $16.2 \%$ & $3.5 \%$ & $5.9 \%$ \\
\hline 26-30 years & $14.9 \%$ & $8.5 \%$ & $9.8 \%$ \\
\hline $31-35$ years & $15.9 \%$ & $13.8 \%$ & $13.7 \%$ \\
\hline $36-40$ years & $12.7 \%$ & $17.6 \%$ & $14.9 \%$ \\
\hline $41-45$ years & $11.5 \%$ & $16.9 \%$ & $14.8 \%$ \\
\hline $46-50$ years & $10.8 \%$ & $15.0 \%$ & $14.0 \%$ \\
\hline $51-55$ years & $7.8 \%$ & $12.0 \%$ & $12.7 \%$ \\
\hline $56-60$ years & $4.3 \%$ & $8.2 \%$ & $8.7 \%$ \\
\hline $61-65$ years & $1.5 \%$ & $3.9 \%$ & $3.6 \%$ \\
\hline \multicolumn{4}{|l|}{ Highest educational level } \\
\hline Primary school less than 9 years & $6.5 \%$ & $13.2 \%$ & $11.0 \%$ \\
\hline Primary school $9(10)$ years & $10.2 \%$ & $16.6 \%$ & $13.4 \%$ \\
\hline Upper secondary 2 years or less & $24.6 \%$ & $24.5 \%$ & $25.8 \%$ \\
\hline Upper secondary 2 years or more & $28.4 \%$ & $19.8 \%$ & $18.2 \%$ \\
\hline Higher education less than 3 years & $14.7 \%$ & $10.6 \%$ & $13.2 \%$ \\
\hline Higher education 3 years or more & $14.5 \%$ & $11.3 \%$ & $14.2 \%$ \\
\hline Post-graduate education & $0.3 \%$ & $0.7 \%$ & $1.6 \%$ \\
\hline Resides in a large city & $63.9 \%$ & $52.8 \%$ & $54.9 \%$ \\
\hline Stockholm & $48.1 \%$ & $34.0 \%$ & $36.3 \%$ \\
\hline Gothenburg & $12.6 \%$ & $10.8 \%$ & $10.3 \%$ \\
\hline Malmoe & $3.2 \%$ & $8.0 \%$ & $8.3 \%$ \\
\hline \multicolumn{4}{|l|}{ Marital status } \\
\hline Married & $41.0 \%$ & $65.3 \%$ & $55.2 \%$ \\
\hline Unmarried & $42.3 \%$ & $17.9 \%$ & $27.1 \%$ \\
\hline Divorced & $15.7 \%$ & $16.0 \%$ & $16.3 \%$ \\
\hline \multicolumn{4}{|l|}{ Country of origin } \\
\hline Nordic countries (except Sweden) & $23 \%$ & $22.0 \%$ & $35.2 \%$ \\
\hline $\mathrm{EU}$ & $7.7 \%$ & $11.7 \%$ & $10.5 \%$ \\
\hline Other European countries & $20.0 \%$ & $17.7 \%$ & $21.1 \%$ \\
\hline Africa & $6.7 \%$ & $3.1 \%$ & $4.7 \%$ \\
\hline North America & $2.6 \%$ & $1.7 \%$ & $2.3 \%$ \\
\hline South America & $8.8 \%$ & $2.1 \%$ & $5.6 \%$ \\
\hline Asia & $29.9 \%$ & $40.7 \%$ & $19.7 \%$ \\
\hline Oceania & $0.1 \%$ & $0.3 \%$ & $0.3 \%$ \\
\hline Soviet Union & $1.2 \%$ & $0.5 \%$ & $0.6 \%$ \\
\hline \multicolumn{4}{|l|}{ Year of immigration } \\
\hline $1936-1965$ & $6.6 \%$ & $12.2 \%$ & $14.6 \%$ \\
\hline 1966-1972 & $12.6 \%$ & $14.2 \%$ & $17.5 \%$ \\
\hline 1973-1985 & $30.9 \%$ & $32.9 \%$ & $29.3 \%$ \\
\hline 1986-1993 & $34.9 \%$ & $32.1 \%$ & $25.9 \%$ \\
\hline 1994-1999 & $13.8 \%$ & $8.5 \%$ & $12.8 \%$ \\
\hline Employed in a TEA & & & $0.6 \%$ \\
\hline Self-employed & & & $7.1 \%$ \\
\hline Number of observations & 2449 & 26159 & 371211 \\
\hline
\end{tabular}


Table 6a. Annual income for those employed in a temporary employment agency in 1999

\begin{tabular}{|c|c|c|c|c|c|c|}
\hline \multirow{2}{*}{ Country of origin } & \multirow{2}{*}{$\begin{array}{c}\text { Number of } \\
\text { observations* }\end{array}$} & \multicolumn{5}{|c|}{ Yearly earnings } \\
\hline & & Mean & Standard deviation & Min & Max & Median \\
\hline$\overline{\text { All }}$ & 18231 & 156188 & 95592 & 180 & 980191 & 147684 \\
\hline Natives & 15812 & 158318 & 97610 & 180 & 980191 & 149127 \\
\hline Immigrants & 2419 & 142263 & 79807 & 187 & 712131 & 135813 \\
\hline
\end{tabular}

Note: * We have excluded all who had an income from self-employment and all with earnings 1 million SEK or larger. In doing so we hope to exclude most of those who are not hired out from the companies but who instead are owners or top managers.

Table 6b. Annual income for those employed in a temporary employment agency in 1999 according to country of origin

\begin{tabular}{|c|c|c|c|c|c|c|}
\hline \multirow[b]{2}{*}{ Country of origin } & \multirow[b]{2}{*}{$\begin{array}{c}\text { Number of } \\
\text { observations }\end{array}$} & \multicolumn{5}{|c|}{ Yearly earnings 1999} \\
\hline & & Mean & $\begin{array}{l}\text { Standard } \\
\text { deviation }\end{array}$ & Min & Max & Median \\
\hline Sweden & 15812 & 158318 & 97610 & 180 & 980191 & 149127 \\
\hline $\begin{array}{l}\text { Nordic countries (except } \\
\text { Sweden) }\end{array}$ & 550 & 163805 & 91517 & 2460 & 712131 & 160632 \\
\hline $\begin{array}{l}\text { EU (except Nordic } \\
\text { countries) }\end{array}$ & 185 & 155372 & 83030 & 5503 & 595000 & 151108 \\
\hline North America & - & - & - & - & - & - \\
\hline Oceania & - & - & - & - & - & - \\
\hline Other European countries & 481 & 141049 & 71374 & 650 & 379002 & 143130 \\
\hline Soviet Union & - & - & - & - & - & - \\
\hline Asia & 731 & 129713 & 74289 & 187 & 531214 & 124262 \\
\hline Africa & 163 & 137059 & 75829 & 27276 & 500584 & 127653 \\
\hline South America & 215 & 125653 & 71979 & 24539 & 408885 & 110403 \\
\hline
\end{tabular}

Note: Fewer than 100 observations from North America, Oceania and Soviet Union.

Table 7. Annual income for self-employed in 1999

\begin{tabular}{l|cccccc}
\hline \multirow{2}{*}{$\begin{array}{l}\text { Country of } \begin{array}{c}\text { origin } \\
\text { orin }\end{array} \\
\text { Number of }\end{array}$} & \multicolumn{5}{c}{ Yearly incomes for self-employed in 1999 } \\
\cline { 3 - 7 } & 189909 & 117749 & 104729 & 1 & 9213361 & 100000 \\
All & 163750 & 121140 & 106375 & 1 & 9213361 & 103794 \\
Natives & 26159 & 96523 & 90944 & 1 & 2632678 & 75000 \\
\hline
\end{tabular}


Table 8. Income regressions for employed in a TEA in 1999

\begin{tabular}{|c|c|c|c|}
\hline & Model 1 & Model 2 & Model 3 \\
\hline Women & $-0.145(0.101)^{* *}$ & $-0.152(0.010)^{* *}$ & $-0.144(0.010)^{* *}$ \\
\hline Age & $0.073(0.003)^{* *}$ & $0.075(0.003)^{* *}$ & $0.073(0.003)^{* *}$ \\
\hline Age squared & $-0.001(0.000)^{* *}$ & $-0.001(0.000)^{* *}$ & $-0.001(0.000)^{* *}$ \\
\hline \multicolumn{4}{|l|}{ Country of origin } \\
\hline Sweden with parents born in Sweden & reference & reference & reference \\
\hline Foreign born & $-0.185(0.015)^{* *}$ & - & - \\
\hline Nordic countries (except Sweden) & & $-0.106(0.028)^{* *}$ & $-0.095(0.028)^{* *}$ \\
\hline EU & - & $-0.131(0.048)^{* *}$ & $-0.125(0.048)^{* *}$ \\
\hline Other European countries & & $-0.238(0.030)^{* *}$ & $-0.228(0.030)^{* *}$ \\
\hline Africa & - & $-0.178(0.051)^{* *}$ & $-0.183(0.051)^{* *}$ \\
\hline Asia & - & $-0.263(0.025)^{* *}$ & $-0.249(0.025)^{* *}$ \\
\hline North America & - & $-0.269(0.082)^{* *}$ & $-0.228(0.082)^{* *}$ \\
\hline South America & - & $-0.170(0.044)^{* *}$ & $-0.150(0.045)^{* *}$ \\
\hline Oceania & - & $-0.232(0.455)$ & $-0.221(0.458)$ \\
\hline Soviet Union & - & $-0.122(0.122)$ & $-0.112(0.123)$ \\
\hline $\begin{array}{l}\text { Born in Sweden with parents born in } \\
\text { another country }\end{array}$ & $-0.024(0.023)$ & $-0.029(0.023)$ & $-0.021(0.0233)$ \\
\hline $\begin{array}{l}\text { Born in Sweden with one parent born in } \\
\text { another country }\end{array}$ & $-0.035(0.015)^{* *}$ & $-0.037(0.015)^{*}$ & $-0.030(0.015)$ \\
\hline \multicolumn{4}{|l|}{ Highest educational level } \\
\hline Primary school less than 9 years & $-0.300(0.028)^{* *}$ & $-0.263(0.028)^{* *}$ & $-0.305(0.028)^{* *}$ \\
\hline Primary school $9(10)$ years & $-0.214(0.016)^{* *}$ & $-0.202(0.016)^{* *}$ & $-0.216(0.016)^{* *}$ \\
\hline Upper secondary 2 years or less & $-0.140(0.014)^{* *}$ & $-0.129(0.014)^{* *}$ & $-0.143(0.014)^{* *}$ \\
\hline Upper secondary 2 years or more & reference & reference & reference \\
\hline Higher education less than 3 years & $-0.039(0.015)^{*}$ & $-0.041(0.015)^{* *}$ & $-0.033(0.015)^{* *}$ \\
\hline Higher education 3 years or more & $0.252(0.019)^{* *}$ & $0.247(0.019)^{* *}$ & $0.258(0.0188)^{* *}$ \\
\hline Post-graduate education & $-0.233(0.174)$ & $-0.214(0.173)$ & $-0.206(0.174)$ \\
\hline \multicolumn{4}{|l|}{ Marital status } \\
\hline Unmarried & reference & reference & reference \\
\hline Married & $0.037(0.013)^{* *}$ & $0.029(0.013)^{*}$ & $0.038(0.013)^{* *}$ \\
\hline Divorced & $-0.010(0.018)$ & $-0.012(0.018)$ & $-0.007(0.018)$ \\
\hline \multicolumn{4}{|l|}{ Resides in a large city } \\
\hline Stockholm & $0.144(0.011)^{* *}$ & - & - \\
\hline Gothenburg & $0.037(0.025)$ & - & - \\
\hline Malmoe & $0.010(0.016)$ & - & - \\
\hline Unemployment in the region & - & - & $-0.058(0.005)^{* *}$ \\
\hline Region & - & Yes & - \\
\hline Constant & $10.286(0.055)^{* *}$ & $10.389(0.055)^{* *}$ & $10.621(0.059)^{* *}$ \\
\hline Adjusted $\mathrm{R}^{2}$ & 0.1505 & 0.1604 & 0.1490 \\
\hline Number of observations & 18249 & 18249 & 18249 \\
\hline
\end{tabular}

$*=$ significant on the $5 \%$ level, $* *=$ significant on the $1 \%$ level $;$ standard errors in parentheses 
Table 9. Income regressions for self-employed in 1999

\begin{tabular}{|c|c|c|c|}
\hline & Model 1 & Model 2 & Model 3 \\
\hline Women & $-0.474(0.007)^{* *}$ & $-0.460(0.008)^{* *}$ & $-0.460(0.008)^{* *}$ \\
\hline Age & $0.136(0.003)^{* *}$ & $0.129(0.003)^{* *}$ & $0.129(0.003)^{* *}$ \\
\hline Age squared & $-0.002(0.000)^{* *}$ & $-0.001(0.000)^{* *}$ & $-0.001(0.000)^{* *}$ \\
\hline \multicolumn{4}{|l|}{ Country of origin } \\
\hline Sweden with parents born in Sweden & reference & reference & reference \\
\hline Foreign born & $-0.424(0.010)^{* *}$ & - & - \\
\hline Nordic countries (except Sweden) & - & $-0.063(0.019)^{* *}$ & $-0.049(0.019)^{*}$ \\
\hline EU & - & $-0.235(0.026)^{* *}$ & $-0.226(0.026)^{* *}$ \\
\hline Other European countries & - & $-0.426(0.021)^{* *}$ & $-0.426(0.021)^{* *}$ \\
\hline Africa & - & $-0.521(0.050)^{* *}$ & $-0.497(0.050)^{* *}$ \\
\hline Asia & - & $-0.675(0.016)^{* *}$ & $-0.659(0.015)^{* *}$ \\
\hline North America & - & $-0.427(0.070)^{* *}$ & $-0.415(0.070)^{* *}$ \\
\hline South America & - & $-0.479(0.0633)^{* *}$ & $-0.459(0.063)^{* *}$ \\
\hline Oceania & - & $-0.0178(0.175)$ & $-0.162(0.176)$ \\
\hline Soviet Union & - & $-0.724(0.0122)^{* *}$ & $-0.703(0.122)^{* *}$ \\
\hline $\begin{array}{l}\text { Born in Sweden with parents born in another } \\
\text { country }\end{array}$ & $-0.052(0.021)^{*}$ & $-0.080(0.021)^{* *}$ & $-0.071(0.021)^{* *}$ \\
\hline $\begin{array}{l}\text { Born in Sweden with one parent born in } \\
\text { another country }\end{array}$ & $-0.060(0.011)^{* *}$ & $-0.066(0.011)^{* *}$ & $-0.061(0.011)^{* *}$ \\
\hline \multicolumn{4}{|l|}{ Highest educational level } \\
\hline Primary school less than 9 years & $-0.073(0.012)^{* *}$ & $-0.034(0.012)^{* *}$ & $-0.042(0.012)^{* *}$ \\
\hline Primary school $9(10)$ years & $-0.075(0.012)^{* *}$ & $-0.063(0.012)^{* *}$ & $-0.063(0.012)^{* *}$ \\
\hline Upper secondary 2 years or less & $-0.062(0.010)^{* *}$ & $-0.056(0.010)^{* *}$ & $-0.058(0.010)^{* *}$ \\
\hline Upper secondary 2 years or more & reference & reference & reference \\
\hline Higher education less than 3 years & $0.002(0.014)$ & $-0.039(0.014)^{* *}$ & $-0.037(0.014)^{*}$ \\
\hline Higher education 3 years or more & $0.079(0.016)^{* *}$ & $0.023(0.016)$ & $0.028(0.016)$ \\
\hline Post-graduate education & $0.079(0.074)$ & $0.051(0.073)$ & $0.054(0.073)$ \\
\hline \multicolumn{4}{|l|}{ Marital status } \\
\hline Unmarried & reference & reference & reference \\
\hline Married & $0.157(0.009)^{* *}$ & $0.171(0.008)^{* *}$ & $0.167(0.008)^{* *}$ \\
\hline Divorced & $0.139(0.012)^{* *}$ & $0.103(0.012)^{* *}$ & $0.102(0.012)^{* *}$ \\
\hline \multicolumn{4}{|l|}{ Resides in a large city } \\
\hline Stockholm & $0.275(0.009)^{* *}$ & - & - \\
\hline Gothenburg & $0.022(0.015)$ & - & - \\
\hline Malmoe & $0.125(0.013)^{* *}$ & - & - \\
\hline Unemployment in the region & - & - & $-0.070(0.004)^{* *_{-}}$ \\
\hline Region & - & Yes & - \\
\hline Industry & & Yes & Yes \\
\hline Constant & $8.547(0.058)^{* *}$ & $8.828(0.058)^{* *}$ & $9.033(0.060)^{* *}$ \\
\hline Adjusted $\mathrm{R}^{2}$ & 0.0624 & 0.0977 & 0.0965 \\
\hline Number of observations & 146393 & 146393 & 146393 \\
\hline
\end{tabular}

$*=$ significant on the $5 \%$ level, $* *=$ significant on the $1 \%$ level; standard errors in parentheses 